Gut, 1988, 29, 522-533

Progress report

\title{
Deoxycholic acid and the pathogenesis of gall stones
}

That deoxycholic acid (DCA) may have a role in cholesterol gall stone formation has been discussed on several occasions ${ }^{1-5}$ but authoritative reviews of gall stone pathogenesis fail to mention this possibility. ${ }^{6-11}$ This may be because the evidence has never been comprehensively reviewed and so its strength is not widely appreciated. Perhaps, too, it is hard to believe that events in the colon can influence the fate of the gall bladder. But the facts suggest that this is indeed the case.

\section{Deoxycholic acid - basic facts}

Because of an efficient enterohepatic circulation, less than $10 \%$ of the circulating bile salt pool reaches the colon each day. ${ }^{12}{ }^{13}$ As bile salts pass down the ileum they are subject to bacterial attack, which may be extensive in the terminal ileum, ${ }^{14}$ but this is usually limited to deconjugation which does not impair absorption. In the colon ${ }^{1516}$ any cholic acid which has escaped absorption in the terminal ileum is rapidly converted to $\mathrm{DCA}^{1718}$ by anaerobic $7 \alpha$-dehydroxylation, ${ }^{14-21}$ so that only small amounts of cholic acid are detectable in the faeces. ${ }^{22}{ }^{23}$ Of the newly formed DCA one third to a half is absorbed by passive diffusion and recirculated. ${ }^{17} 1824$ In normal subjects this amounts to about $150 \mathrm{mg}$ per day, ${ }^{25}$ the remainder being precipitated or adsorbed to solid matter and lost in the faeces. The circulating pool of DCA is about $500 \mathrm{mg}(1.25 \mathrm{mmol})^{25}$ and DCA constitutes $10-40 \%$ of the bile acids in bile.

\section{Epidemiological relationships}

The established risk factors (in the sense of personal characteristics) for cholesterol rich gall stones are increasing age, female sex, parity, obesity, and raised plasma triglycerides. ${ }^{26}$ It is not widely appreciated that some of these risk factors are associated with increased concentrations of DCA in bile. With respect to age, the pool of circulating DCA was found to be significantly larger in a group of elderly Dutch people than in a group of young ones. ${ }^{27}$ With respect to sex, the bile of healthy age matched men and women has not often been compared but in a Canadian study there was a trend towards more DCA in the bile of women. ${ }^{28}$ In a small Australian study the women had $25 \%$ of DCA in their duodenal bile acids while men had only $9 \%{ }^{29}$ and, in Sweden, hyperlipoproteinaemic women had more DCA in their bile than men. ${ }^{30}$ With respect to hypertriglyceridaemia, Swedish people with type IIB and type IV hyperlipoproteinemia had $39 \%$ and $41 \%$ DCA in their bile while healthy controls had only $23 \% .{ }^{30}$

Vegetarian women have a lower than expected prevalence of gall stones (explained only in part by their tendency to be slim).${ }^{31}$ They have also been 
reported to have small DCA pools $-18 \mu \mathrm{mol} / \mathrm{kg}$ compared with $29 \mu \mathrm{mol} / \mathrm{kg}$ in age matched meat eaters. ${ }^{32}$

Thus four risk factors for gall stones - age, female sex, hypertriglyceridaemia and not being a vegetarian - are associated with increased concentrations of DCA in bile. The other risk factors (parity and obesity) have not been looked at from this point of view.

\section{Raised proportion of deoxycholic acid in the bile of gall stone patients}

In 1971 van der Linden ${ }^{33}$ observed that there was an increase in the ratio of dihydroxy bile acids (deoxycholic and chenodeoxycholic acid) to trihydroxy bile acids (cholic) in subjects with gall stones. He suggested that the shift towards dihydroxy bile acids favoured gall stone formation. This shift is now known to be caused by an increase in DCA. In 19 publications there have been 20 comparisons of the bile acid composition of gall stone subjects and controls. ${ }^{28{ }^{3451}}$ In 19 comparisons the proportion of DCA was higher in the gall stone subjects and in one there was no difference (Figure). In seven of the studies the difference was reported as statistically significant ${ }^{284243454751}$ and in another two ${ }^{35}{ }^{36}$ the difference was marked but tests of significance were not reported. In one of the latter studies ${ }^{36}$ the data allow statistical

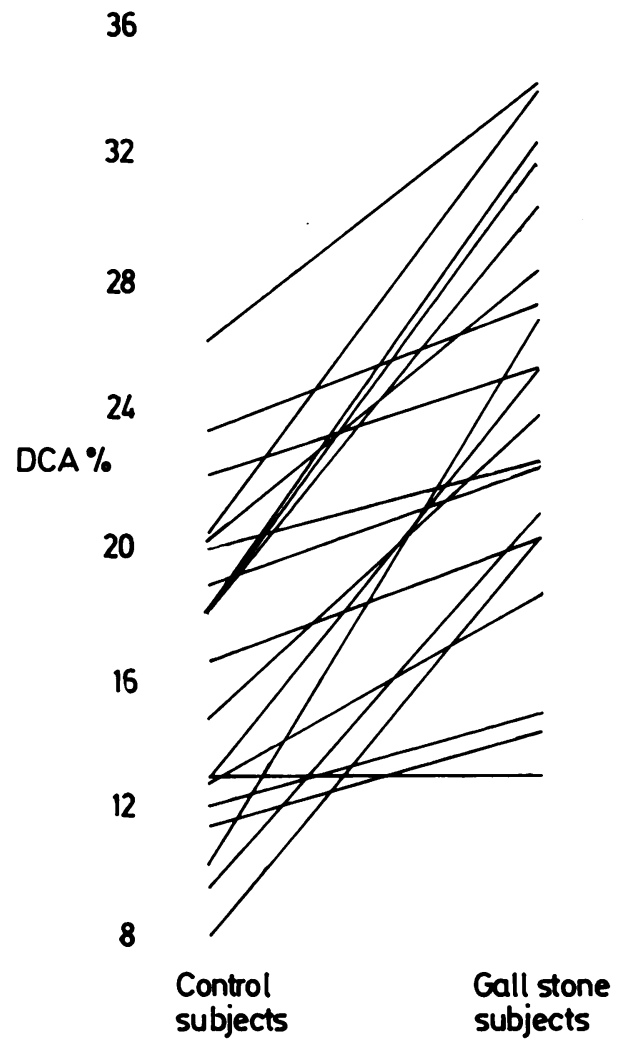

Figure Mean percentage of deoxycholic acid (DCA) in the duodenal bile acids of subjects with gall stones and of controls; results from 20 published studies. 
testing and a significant difference is indeed present. In the remaining studies the difference was not significant but, with one exception, ${ }^{18}$ the difference has always been in the same direction. Such conformity is unlikely to be due to chance.

\section{Relationship between the proportion of DCA in bile and biliary saturation with cholesterol}

In several groups of subjects, including the 280 men in the US Cooperative Gallstone Study, a significant correlation has been shown between the proportion of DCA in duodenal bile acids and the moles \% cholesterol or cholesterol saturation index (CSI) of gall bladder bile ${ }^{51152-54}$ (or hepatic bile $^{55}$ ). Similarly, we found a correlation between artificially induced changes in these two parameters. ${ }^{25}$ Subjects with type IIb and IV hyperlipoproteinaemia who, as noted, have a significantly higher proportion of DCA in their bile than healthy controls generally have bile supersaturated with cholesterol. ${ }^{311}$

These findings and the other associations between gall stone risk factors and raised \% DCA in bile suggest that the excess of DCA in the bile of gall stone subjects is not secondary to their gall stones but, rather, that it antedates the gall stones and favours the formation of supersturated bile, which is the metabolic precursor of cholesterol gall stone formation. If this is so, any agent or manoeuvre which causes a change in the DCA content of bile should also induce a change in CSI in the same direction.

\section{Manoeuvres which reduce DCA in bile}

Wheat bran was the first agent shown to alter DCA metabolism ${ }^{56}$ and it has been repeatedly confirmed that bran lowers \% DCA in bile ${ }^{+3(0)+1)}$ (although, not surprisingly, the change is less marked or absent if the initial level of DCA is $\left.l_{0}{ }^{24} 6162\right)$. At the same time, provided that bile is initially supersaturated, wheat bran causes a significant reduction in biliary cholesterol saturation (Table 1). ${ }^{99+3576162}$ The effects of bran on bile have recently been reviewed. ${ }^{6.3}$

Other ways have been devised of lowering the amount of deoxycholic acid in bile in order to study how this would affect biliary CSI (Table 1). In the first such study, metronidazole was supplied to healthy men for 10 days in order to inhibit anaerobic bacterial activity in the colon and interfere with dehydroxylation of cholic acid. The percentage of DCA fell in all subjects and the CSI fell in all but one of them. ${ }^{\text {in }}$ In another study, ampicillin was found to have similar effects on bile, probably for the same reasons, when given to subjects with or without gall stones. ${ }^{65 t 6}$ In a different approach to the same problem, the synthetic, unabsorbed disaccharide lactulose was administered to healthy middle aged women. Lactulose acidifies the right side of the colon, thereby inhibiting bacterial $7 \alpha$-dehydroxylases which are inactive at $\mathrm{pH}<6$. It lowered the percentage of DCA in duodenal bile acids in all the subjects and the CSI in all but one. ${ }^{67}$ The ingestion of a preparation of live Streptococcus faecium had similar effects on bile, probably by displacing the anaerobic organisms in the colon. ${ }^{6 *}$ When patients with hypothyroidism were treated with L-thyroxine, there was a significant fall in $\%$ DCA in the bile and in CSI. ${ }^{69}$ At the time these findings were unexplained 
but it can now be postulated that they were due to speeding up of colonic transit as constipation is a feature of hypothyroidism and it has recently been observed that relief of constipation is associated with a fall in the concentration of DCA in bile as well as a fall in CSI..5

Thus, all seven agents which lower DCA in bile lower the CSI at the same time.

\section{Manoeuvres which increase DCA in bile (Table 2)}

Impressed by the discovery (in their own laboratory ${ }^{57}$ ) that the fall in $\%$ DCA induced by bran is accompanied by a fall in the cholesterol content of bile, Low-Beer and Pomare decided to see what happens when \% DCA is artificially increased. They fed physiological quantities of DCA (100-150 $\mathrm{mg}$ /day) to healthy volunteers and found a significant increase in moles \% cholesterol in bile.' These findings aroused much interest and three other groups tried to reproduce them. ${ }^{6071472}$ Only one succeeded in doing so. ${ }^{66}$ This may be because in these further studies the DCA was administered in pharmacological doses (750-1000 mg/day) and not in the physiological amounts of the original experiment. In large doses, DCA inhibits

Table 1 Summary of published studies which report the cholesterol saturation index of 'gall bladder bile' (CSI) before and after a regimen that lowers the deoxycholic acid $(D C A)$ content of bile. 'Gall bladder bile' was obtained by duodenal drainage afterinduced gall bladder contraction

\begin{tabular}{|c|c|c|c|c|c|c|c|c|c|c|c|}
\hline \multirow[b]{2}{*}{$\begin{array}{l}\text { City and } \\
\text { reference }\end{array}$} & \multirow[b]{2}{*}{$\begin{array}{l}\text { Subjects } \\
\text { (male, female) }\end{array}$} & \multirow{2}{*}{$\begin{array}{l}\text { Age (mean } \\
\text { orrange) } \\
y r\end{array}$} & \multicolumn{3}{|c|}{ Details of regimen } & \multicolumn{3}{|c|}{$\begin{array}{l}\text { Mean } \% \text { deoxycholic } \\
\text { acid in duodenal bile acids }\end{array}$} & \multicolumn{3}{|c|}{$\begin{array}{l}\text { Mean cholesterol } \\
\text { saturation index }\end{array}$} \\
\hline & & & Agent & Daily dose & $\begin{array}{l}\text { Duration } \\
\text { (weeks) }\end{array}$ & Before & After & pvalue & Before & After & pvalue \\
\hline Bristol ${ }^{42}$ & $\begin{array}{l}10 \mathrm{f} \\
\text { Gall stones }\end{array}$ & $33-53$ & Wheat bran & 2()$-40 \mathrm{~g}$ & $4-6$ & - $^{*}$ & - $^{*}$ & - & 1.49 & 1.29 & $<0 \cdot 05$ \\
\hline Edmonton ${ }^{43}$ & $9(? \operatorname{sex})$ & Not stated & Wheat bran & $50 \mathrm{~g}$ & 4 & $31 \cdot 3$ & $23 \cdot 3$ & $<0 \cdot(05$ & 1.43 & 0.76 & $<() \cdot 01$ \\
\hline Adelaide-" & $\begin{array}{l}5 \mathrm{f} \\
\text { Healthy but } \\
\text { supersatd bile }\end{array}$ & 23 & Wheat bran & $30 \mathrm{~g}$ & 8 & $29 \cdot 8$ & $21 \cdot 9$ & SNA & $1 \cdot 36$ & 0.95 & SNA \\
\hline Bristol $^{(x)}$ & $\begin{array}{l}4 \mathrm{~m}, 16 \mathrm{f} \\
\text { Constipated }\end{array}$ & 49 & $\begin{array}{l}\text { Trifyba } \\
(80 \% \text { wheat } \\
\text { fibre })\end{array}$ & $\begin{array}{l}10-32 \mathrm{~g} \\
\quad(\operatorname{mean} 20 \mathrm{~g})\end{array}$ & $6-12$ & $26 \cdot 6$ & $23 \cdot 0$ & $<0 \cdot(002$ & $1 \cdot 13 \dagger$ & $1.07 \dagger$ & $=0.049 \dagger$ \\
\hline Birmingham ${ }^{\text {tot }}$ & $\begin{array}{l}11 \mathrm{~m} \\
\text { Healthy }\end{array}$ & $21-46$ & Metronidazole & $2 \mathrm{~g}$ & 1.4 & $24 \cdot()$ & $6 \cdot 6$ & $<() \cdot(x) 1$ & $1 \cdot 0$ & $0 \cdot 83$ & $<(0 \cdot 0) 1$ \\
\hline Modena $a^{6.5}$ & $\begin{array}{l}3 \mathrm{~m}, 2 \mathrm{f} \\
\text { Gall stones }\end{array}$ & 57 & Ampicillin & $2 g$ & $2-3$ & $24 \cdot() \ddagger$ & $5 \cdot 4 \ddagger$ & SNA & $1 \cdot 25$ & 0.95 & SNA \\
\hline Modena $a^{(x)}$ & $\begin{array}{l}3 \mathrm{~m}, 2 \mathrm{f} \\
3 \text { with Gall } \\
\text { stones }\end{array}$ & 50 & Ampicillin & $40 \mathrm{mg} / \mathrm{kg}$ & 3 & $25 \cdot 1$ & $13 \cdot 4$ & SNA & $1 \cdot 33$ & $1 \cdot 12$ & SNA \\
\hline Bristol $^{67}$ & $\begin{array}{l}10 \mathrm{f} \\
\text { Healthy }\end{array}$ & 46 & Lactulose & $\begin{array}{l}39-60 \mathrm{~g} \\
\quad(\text { mean } 56 \mathrm{~g})\end{array}$ & 6 & $28 \cdot 4$ & $15 \cdot 6$ & $<0 \cdot(0) 2$ & $1 \cdot 40$ & $1 \cdot 19$ & $<0 \cdot 005$ \\
\hline Modena ${ }^{6 x}$ & $\begin{array}{l}5 \mathrm{~m}, 3 \mathrm{f} \\
\text { Healthy }\end{array}$ & $41-69$ & Strep. faccium & $\begin{array}{l}750 \times 10^{\circ} \\
\text { bacteria }\end{array}$ & 4 & $23 \cdot 6$ & $18 \cdot 4$ & $<0 \cdot 01$ & $1 \cdot 05$ & 0.98 & $<0 \cdot 05$ \\
\hline Stockholm ${ }^{69}$ & $\begin{array}{l}2 \mathrm{~m}, 8 \mathrm{f} \\
\text { Hypo- } \\
\text { thyroidism }\end{array}$ & 59 & L-thyroxine & $\begin{array}{l}\text { As required to } \\
\text { normalise } \\
\text { TSH levels }\end{array}$ & $16-48$ & $30 \cdot 0$ & $19 \cdot 0$ & $<0 \cdot(0) 1$ & $1.35 \$$ & $1 \cdot 08 \S$ & NS§ \\
\hline Bristol $^{25}$ & $\begin{array}{l}2 \mathrm{~m}, 14 \mathrm{f} \\
\text { Constipation }\end{array}$ & ${ }^{48}(38-69)$ & Senna laxative & $15-60 \mathrm{mg}$ & 6 & $25 \cdot 9$ & $17 \cdot 2$ & $<0 \cdot(00) 1$ & $1 \cdot 20 \|$ & $0.99 \|$ & $=0 \cdot(004 \|$ \\
\hline
\end{tabular}

${ }^{*}$ DCA measured in only four subjects, it fell in all, by mean of $10 \cdot 2 \%$; tof 12 subjects with CSI initially $>1 \cdot 0$. CSI fell in nine; mean fall $1 \cdot 33$ to 1.22, $p=0.008$; $\ddagger$ calculated from published values for bile acid pool sizes; §of seven subjects with CSI initially $>1 \cdot()$, CSI fell in six, mean fall from 1.31 to 1.12; $\|$ one 'rogue' CSI result excluded, of eight subjects with CSI initially $>1 \cdot($ ). CSI fell in six; mean fall 1.40 to 1.20, $p=0 \cdot 02$; SNA statistics not applied because of small numbers. 
cholesterol absorption ${ }^{(x)}$ and may even have direct toxic effects on the small intestine. ${ }^{73-75}$ A toxic effect on the liver is also possible. ${ }^{7076}$

Three studies of more appropriate design have recently been reported and all have supported the observation of Low-Beer and Pomare. Carulli et al ${ }^{6.5}$ increased DCA input by physiological amounts when they administered cholic acid, the precursor of DCA, to 10 subjects with gall stones in doses which led to a rise in \% DCA from 21.8 to 35.4 . The CSI of bile also rose significantly. The same group has studied patients with cirrhosis, who tend to have a low concentration of DCA in their bile ${ }^{77}$ and a low CSI. ${ }^{78}$ When such patients were fed small quantities of DCA (about $200 \mathrm{mg} / \mathrm{day}$ ), their cholesterol saturation index rose significantly, returning to the original value after DCA ingestion was stopped. ${ }^{79}$ Finally, when we slowed down the intestinal transit of healthy volunteers with loperamide their circulating DCA pools expanded significantly and there was a rise in biliary CSI. ${ }^{25}$

Thus, a large number of studies indicate that any regimen which alters the amount of DCA in the bile acid pool (other than pharmacological doses of DCA) induces a change in the CSI of bile in the same direction. This strongly suggests that DCA directly affects the cholesterol saturation of bile. The relevant factor may not be \% DCA as such but the size of the circulating DCA pool because, in our own study with loperamide, ${ }^{25}$ a rise in CSI was associated with no change in \% DCA even though the DCA pool had expanded (the total bile acid pool having expanded at the same time).

\section{Mechanism of the DCA effect on cholesterol saturation of bile}

How DCA influences the CSI of bile remains to be established but there are two ways in which it could increase cholesterol secretion into bile. Increased

Table 2 Summary of published studies which report the cholesterol saturation of 'gall bladder bile' before and after a regimen that raises the deoxycholic acid (DCA) content of bile

\begin{tabular}{|c|c|c|c|c|c|c|c|c|c|c|c|}
\hline \multirow{3}{*}{$\begin{array}{l}\text { City and } \\
\text { reference }\end{array}$} & \multirow{3}{*}{$\begin{array}{l}\text { Subjects } \\
\text { (male, female) }\end{array}$} & \multirow{3}{*}{$\begin{array}{l}\text { Mean age } \\
\text { and/or } \\
\text { range (yr) }\end{array}$} & \multicolumn{3}{|c|}{ Details of regimen } & \multirow{2}{*}{\multicolumn{3}{|c|}{$\begin{array}{l}\text { Mean \% deoxycholic } \\
\text { acid in duodenal bile acids }\end{array}$}} & \multirow{2}{*}{\multicolumn{3}{|c|}{$\begin{array}{l}\text { Mean cholesterol saturation } \\
\text { index or moles \% cholesterol }\end{array}$}} \\
\hline & & & & & Duration & & & & & & \\
\hline & & & Agent & Daily dose & (days) & Before & After & pvalue & Before & After & pvalue \\
\hline Bristol $^{1}$ & $\begin{array}{l}9 \mathrm{~m} .7 \mathrm{f} \\
\text { Healthy }\end{array}$ & $21-54$ & DCA & $1(0)-150 \mathrm{mg}$ & 14 & $21^{*}$ & $50 *$ & $<0 \cdot(0) 1$ & $8.6 \%$ & $9.9 \%$ & $<() \cdot(0) 1$ \\
\hline Rochester $^{71}$ & $7 \mathrm{f}$ & $22-34$ & DCA & $750 \mathrm{mg}$ & 4()$\pm 6$ & 26 & 75 & DNG & 0.86 & 0.83 & $\mathrm{NS}^{+}$ \\
\hline Stockholm ${ }^{70}$ & $\begin{array}{l}8 \mathrm{f} \\
\text { Healthy }\end{array}$ & ${ }^{37}(22-59)$ & DCA & $750 \mathrm{mg}$ & $21-28$ & 20 & 87 & DNG & $8.8 \%$ & $8 \cdot 6 \%$ & $\mathrm{NS}^{\dagger}$ \\
\hline Modena $^{72}$ & $4 m, 5 f$ & 49 & DCA & $15 \mathrm{mg} / \mathrm{kg}$ & $7-14$ & 16 & 89 & DNG & $1 \cdot 23$ & $1 \cdot 21$ & NS ${ }^{+}$ \\
\hline Modenath & $\begin{array}{l}6 \mathrm{~m}, 3 \mathrm{f} \\
5 \text { Gall stones }\end{array}$ & 43 & DCA & $15 \mathrm{mg} / \mathrm{kg}$ & 21 & $20 \cdot 1$ & $78 \cdot 6$ & $<() \cdot(0) 1$ & 1.41 & $1 \cdot 82$ & $<0 \cdot(12+$ \\
\hline Modena $^{74}$ & $11 \mathrm{~m}$ & 56 & DCA & $180-250 \mathrm{mg}$ & $21-28$ & $5 \cdot 3$ & $43 \cdot 9$ & $<0 \cdot(001$ & 0.92 & $1 \cdot 34$ & $<0 \cdot(0) 5$ \\
\hline Modena ${ }^{65}$ & $\begin{array}{l}10(\text { most } f) \\
\text { Gall stones }\end{array}$ & 51 & Cholic acid & $15 \mathrm{mg} / \mathrm{kg}$ & $14-21$ & $21 \cdot 8$ & 35.4 & $<(1) \cdot(0) 1$ & $1 \cdot 07$ & $1 \cdot 42$ & $<0 \cdot(0) 1$ \\
\hline Bristol $^{25}$ & $\begin{array}{l}2 \mathrm{~m}, 10 \mathrm{f} \\
\text { Healthy }\end{array}$ & $45(38-62)$ & Loperamide & $\begin{array}{l}4-2() \mathrm{mg} \\
\text { Sufficient to } \\
\text { cause } \\
\text { constipation }\end{array}$ & 42 & $0.40 \mathrm{~g} \ddagger$ & $0.57 \mathrm{~g} \ddagger$ & $=0.0018$ & $1 \cdot 10$ & $1 \cdot 20$ & $=0 \cdot(01$ \\
\hline
\end{tabular}

*\% DCA values obtained in a subgroup of seven subjects given DCA for 6-16 days; tdose of DCA was pharmacological, not physiological, so data hard to interpret (see text); $\ddagger$ DCA pool, measured by isotope dilution; DNG data not given but clearly significant; NS not significant $(p>0 \cdot 05)$. 
cholesterol secretion is accepted as the major biochemical defect in most cases of cholesterol rich gall stones. ${ }^{610}$

Deoxycholic acid is very hydrophobic ${ }^{76}$ and, of all the major bile acids, it has the strongest detergent property. ${ }^{2}$ As bile acids pass into the biliary canaliculus they may leach out cholesterol from the cell membrane ${ }^{801}$ as distinct from the cholesterol which is excreted in vesicles; if so DCA is likely to do this to a greater extent than the other bile acids. Increased cholesterol secretion has been shown in acute experiments when the natural bile acid pool was drained and replaced by DCA. ${ }^{76}$ Whether the same thing happens with chronic changes in bile acid composition is less certain but seems likely from recent studies. Thus, when DCA $400 \mathrm{mg} / \mathrm{day}$ was fed to normal volunteers for four weeks, hepatic secretion of cholesterol (measured over an eight hour period) increased by $11 \%(0 \cdot 05<\mathrm{p}<0 \cdot 10) .{ }^{82}$ Von Bergmann $^{83}$ has reported that the secretion of DCA is increased in gall stone patients and that it correlates with cholesterol secretion.

Another way DCA may act on the CSI is through displacement of the other dihydroxy bile acid chenodeoxycholic acid (CDCA) from the bile acid pool. Pomare and Low-Beer ${ }^{84}$ were the first to notice that, when bile acid composition is examined in a large group of people with a wide range of values, there is a reciprocal relationship between \% DCA and \% CDCA, whereas there is little or no relationship between $\%$ DCA and $\%$ cholic acid. This has been confirmed in another very large study ${ }^{52}{ }^{85}$ though not in a third, smaller one. ${ }^{70}$ In several studies an induced change in \% DCA has been accompanied by a significant reciprocal change in \% CDCA with little or no change in \% cholic acid. ${ }^{25664678486}$ Orally administered CDCA is known to have an inhibitory effect on cholesterol secretion ${ }^{87}$ and to lessen the cholesterol saturation of bile..$^{388}$ Therefore, high concentrations of DCA might reduce the curbing effect of endogenous CDCA on cholesterol secretion. This hypothesis ${ }^{84}$ is attractive and, at first sight, plausible, but the evidence is weak. Published dose reponse relationships do not permit the conclusion that cholesterol secretion is influenced by changes in \% CDCA as small as those which accompany changes in \% DCA. ${ }^{89}$

As to how DCA displaces CDCA from the bile acid pool, one small study suggests that it is by inhibition of CDCA synthesis. ${ }^{84}$ Another possibility is that DCA conjugates compete with CDCA conjugates for absorption from the ileum. ${ }^{85}$

\section{Other physiological effects of DCA relevant to gall stone formation}

Besides its effect on cholesterol secretion DCA could influence cholesterol gall stone formation by an effect on nucleating mechanisms. Although supersaturated bile is a prerequisite for gall stone formation ${ }^{9091}$ nucleation of cholesterol crystals is also crucially important, at least when bile is only moderately supersaturated, that is, in the metastable labile zone. ${ }^{1092-95}$ Possible nucleating factors include mucin. ${ }^{10}$ This seems a plausible candidate because many gall stones have a core of mucin. Hypersecretion of mucin by the gall bladder mucosa occurs when bile is supersaturated but the stimulus for this hypersecretion seems not to be excess biliary cholesterol as such ${ }^{96}$ but rather an increase in the amount of phospholipid containing arachidonic acid. ${ }^{9798}$ Arachidonic acid is the precursor of prostaglandins. It has been suggested that prostaglandins stimulate mucin secretion from the gall 
bladder mucosa as the anti-prostaglandin agent aspirin inhibits mucin release and gall stone formation in the prairie dog. ${ }^{96}$ Similarly, indomethacin is said to inhibit prostaglandin release and gall bladder mucin secretion. ${ }^{99}$ In a recent study of healthy subjects, a significant correlation $(r=0.71)$ was found between \% DCA in the bile acid pool and the amount of arachidonic acid in the phospholipids of bile. ${ }^{100}$ The mechanism of this relationship is unclear but it raises the possibility that bile with a high DCA concentration is prone to gall stone formation because it favours nucleation through increased biliary mucin. Nevertheless, it is far from certain that mucus glycoprotein is an important nucleating agent. ${ }^{101}$

Deoxycholic acid may influence cholesterol crystallisation in a more direct way. In artificial bile, nucleation time is reported to be shorter if the predominant bile acid is the taurine conjugate of DCA than if it is the taurine conjugate of chenodeoxycholic or cholic acid. ${ }^{100}$ If this can also be shown to be true of native bile the implications in terms of gall stone formation are apparent.

\section{Problems and areas of ignorance}

Female villagers in rural Zimbabwe have Western concentrations of DCA in their bile yet their gall bladder bile remains unsaturated. ${ }^{102}$ Tongan islanders actually have more DCA in their bile than New Zealand Tongans, ${ }^{103}$ yet they are thought rarely to develop gall stones. These findings are paradoxical but suggest that, in non-Westernised communities, there are unidentified protective factors against supersaturated bile and gall stones.

In the 264 women in the US National Cooperative Gallstone Study the correlation between \% DCA and moles \% cholesterol in bile was not significant. ${ }^{52}$ It was, however, in the same direction as in the men. Deoxycholic acid is only one of the variables affecting bile. Women have more such variables than men, namely, parity and oestrogenic activity.

In one bran feeding study ${ }^{62}$ there was a fall in biliary CSI from initially supersaturated concentrations despite no change in \% DCA. The initial level of DCA, however, was low. The fact that, despite this, bran lowered the CSI is hard to explain but wheat bran is a complex and heterogeneous product. In our own study with a concentrate of bran $^{(0)}$ we found no correlation between change in CSI and change in \% DCA suggesting that wheat fibre may affect bile in more than one way.

Patients with colonic adenomas tend to have large DCA pools; $;{ }^{104}$ it would be interesting to know whether they have an increased prevalence of gall stones.

Little is known of the physiological variables which determine the size of the circulating DCA pool and the proportion of DCA in bile other than intestinal transit time $e^{25}$ and the intake of dietary fibre..$^{5676186}$ Older people have a larger DCA pool, ${ }^{27}$ more saturated bile ${ }^{105} 106$ and a higher prevalence of gall stones than younger people. Their increased DCA pools could simply be because of the slowing of colonic transit which tends to occur with age. Research is, however, needed on other physiological determinants of DCA formation and absorption. The $\mathrm{pH}$ and bacterial flora of the colonic contents are likely candidates because there is a relationship between DCA input and the ratio of anaerobes to aerobes in the faeces. ${ }^{107}$

Finally, attention should be given to the frequency of enterohepatic 
circulation of the bile salt pool. More frequent circulation has been suggested as the cause of the small pool in gall stone subjects. ${ }^{108-110} \mathrm{By}$ analogy with the situation after cholecystectomy it could perhaps also explain the increased proportion of DCA in the bile of gall stone subjects, as more frequent circulation results in more exposure of bile salts to intestinal bacteria and so greater dehydroxylation of cholic acid..$^{4111-113}$

\section{Conclusion}

Much evidence suggests that high concentrations of deoxycholic acid in the circulating bile salt pool promote the hepatic secretion of cholesterol and hence supersaturation of bile. They may also promote the nucleation of cholesterol crystals in bile. Deoxycholic acid deserves recognition as a factor in the pathogenesis of cholesterol rich gall stones which helps to explain the increasing prevalence of gall stones with age and their lower prevalence in vegetarians.

University Department of Medicine,

S N MARCUS AND K W HEATON

Bristol Royal Infirmary,

Bristol BS2 8HW

\section{References}

1 Low-Beer TS, Pomare EW. Can colonic bacterial metabolites predispose to cholesterol gall stones? Br Med J 1975; 1: 438-40.

2 Carulli N, Ponz de Leon M. How does bile acid pool composition regulate bile cholesterol saturation? Ital J Gastroenterol 1982; 14: 179-83.

3 Capocaccia L. How does bile acid pool composition regulate bile cholesterol saturation? Ital J Gastroenterol 1982; 14: 184-5.

4 van der Werf SDJ, van Berge Henegouwen GP. Biliary bile acid composition and cholesterol saturation. Gastroenterology 1983; 84: 1074-7.

5 Heaton KW. Bile salts. In: Wright R, Alberti KGMM, Karran S, Millward-Sadler GH, eds. Liver and biliary disease 2nd ed. London: Saunders, 1985: 277-99.

6 Bennion LJ, Grundy SM. Risk factors for the development of cholelithiasis in man. NEngl J Med 1978; 299: 1161-7 (Part I) and 2221-7 (Part II).

7 Bouchier IAD. Biochemistry of gallstone formation. Clin Gastroenterol 1983; 12: 25-48.

8 Grundy SM. Mechanism of cholesterol gallstones formation. Sem Liver Dis 1983; 3: 97-111.

9 Holzbach RT. Pathogenesis and medical treatment of gallstones. In: Sleisenger MH, Fordtran JS, eds. Gastrointestinal disease: pathophysiology, diagnosis, treatment. 3rd ed. Philadelphia: Saunders, 1983; 1356-73.

10 Bouchier IAD. Debits and credits: a current account of cholesterol gallstone disease. Gut 1984; 25: 1021-8.

11 Bouchier IAD. Pathogenesis. In: Jewell DP, Ireland A, eds. Topics in gastroenterology 14. Oxford: Blackwell, 1986: 75-83.

12 Hepner GW, Hofmann AF, Thomas PJ. Metabolism of steroid and amino acid moieties of conjugated bile acids in man. II. Glycine-conjugated dihydroxy bile acids. J Clin Invest 1972; 51: 1898-905.

13 Hepner GW, Sturmann JA, Hofmann AF, Thomas PJ. Metabolism of steroid and amino acid moieties of conjugated bile acids in man. III Cholyltaurine (taurocholic acid). $J$ Clin Invest 1973; 52: 433-40.

14 Northfield TC, McColl I. Postprandial concentrations of free and conjugated bile acids down the length of the normal human small intestine. Gut 1973; 14: 513-8.

15 Percy-Robb IW, Jalan KN, McManus JPA, Sircus W. Effect of ileal resection on bile salt metabolism in patients with ileostomy following proctocolectomy. Clin Sci 1971; 41: 371-82. 
16 Morris JS, Low-Beer TS, Heaton KW. Bile salt metabolism and the colon. Scand J Gastroenterol 1975; 8: 425-31.

17 Samuel P, Saypol GM, Meilman E, Mosbach EH, Chafizadeh M. Absorption of bile acids from the large bowel in man. J Clin Invest 1968; 47: 2070-8.

18 Morris JS, Heaton KW. The fate of labelled bile salts introduced into the colon. Scand J Gastroenterol 1974; 9: 33-9.

19 Aries VC, Hill MJ. Degradation of steroids by intestinal bacteria. II Enzymes catalysing the oxido-reduction of the $3 \alpha-, 7 \alpha-$ and $12 \alpha-$ hydroxyl groups in cholic acid, and the dehydroxylation of the 7 hydroxyl group. Biochim Biophys Acta 1970; 202: 535-43.

20 Stellwag EJ, Hylemon PB. $7 \alpha$-dehydroxylation of cholic acid and chenodeoxycholic acid by Clostridium leptum. J Lipid Res 1979; 20: 325-33.

21 Hylemon PB, Cacciupuotti AF, White BA, Whitehead TR, Frickle FJ. $7 \alpha$-dehydroxylation of cholic acid by cell extracts of Eubacterium species VP12708. Am J Clin Nutr 1980; 33: 2507-10.

22 Wynder EL, Reddy BS. Metabolic epidemiology of colorectal cancer. Cancer 1974; 34: 801-6.

23 Moskovitz M, White C, Barnett RN, et al. Diet, fecal bile acids and neutral sterols in carcinoma of the colon. Dig Dis Sci 1979; 24: 746-51.

24 Hepner GW, Hofmann AF, Thomas PJ. Metabolism of steroid and amino-acid moieties of conjugated bile acids in man. I Cholyglycine (glycocholic acid). J Clin Invest 1972; 51: 1889-97.

25 Marcus SN, Heaton KW. Intestinal transit, deoxycholic acid and the cholesterol saturation of bile - three inter-related factors. Gut 1986; 27: 550-8.

26 Capocaccia L, Ricci G, Angelico F, Angelico M, Attili AF, eds. Epidemiology and prevention of gallstone disease. Lancaster: MTP Press, 1984.

27 van der Werf SDJ, Huijbregts AWM, Lamers HLM, van Berge Henegouwen GP, van Tongeren JHM. Age dependent differences in human bile acid metabolism and $7 \alpha-$ dehydroxylation. Eur J Clin Invest 1981; 11: 425-31.

28 Fisher MM, Youssef IM. Sex differences in the bile acid composition of human bile: studies in patients with and without gallstones. Can Med Assoc J 1973; 109: 190-3.

29 Watts J McK, Jablonski P, Toouli J. The effects of added bran to the diet on the saturation of bile in people without gallstones. Am J Surg 1978; 135: 321-4.

30 Ahlberg J, Angelin B, Einarsson K, Hellström K, Leijd B. Biliary lipid composition in normo- and hyperlipoproteinemia. Gastroenterology 1980; 79: 90-4.

31 Pixley F, Wilson D, McPherson K, Mann J. Effect of vegetarianism on development of gallstones in women. $\mathrm{Br}$ Med J 1985; 291: 11-2.

32 Hepner GW. Altered bile acid metabolism in vegetarians. Am J Dig Dis 1975; 20: 935-40.

33 Van der Linden W. Bile acid pattern of patients with and without gallstones. Gastroenterology 1971; 60: 1144-5.

34 Sjövall $\mathbf{J}$. Bile acids in man under normal and pathological conditions. Clin Chim Acta 1960; 5: 33-41.

35 Burnett W. Pathogenesis of gallstones. In: Taylor W, ed. The biliary system. Oxford: Blackwell, 1965: 601-4.

36 Nakayama F, van der Linden W. Bile from gallbladder harboring gallstones: can it indicate stone formation? Acta Chir Scand 1970; 136: 605-10.

37 Vlahcevic ZR, Bell CC, Buhac I, Farrar JT, Swell L. Diminished bile acid pool size in patients with gallstones. Gastroenterology 1970; 59: 165-73.

38 Thistle JL, Schoenfield LJ. Lithogenic bile among young Indian women. Lithogenic potential decreased with chenodeoxycholic acid. N Engl J Med 1971; 284: 177-81.

39 Vlahcevic ZR, Bell CC, Gregory DH, Buker G, Juttijudata P, Swell L. Relationship of bile acid pool size to the formation of lithogenic bile in female Indians of the South-West. Gastroenterology 1972; 62: 73-83.

40 Pomare EW, Heaton KW. Bile salt metabolism in patients with gallstones in functioning gallbladders. Gut 1973; 14: 885-90.

41 Hepner GW, Hofmann AF, Malagelada JR, Szczepanik PA, Klein PD. Increased bacterial degradation of bile acids in cholecystectomised patients. Gastroenterology 1974; 66: $556-64$.

42 McDougall RM, Walker K, Thurston OG. Bile acid alterations in patients with cholesterol gallstones. J Surg Res 1976; 21 : 233-7.

43 McDougall RM, Yakymyshyn L, Walker K, Thurston OG. The effect of wheat bran on serum lipoproteins and biliary lipids. Can J Surg 1978; 21: 433-5.

44 Carulli N, Ponz de Leon M, Zironi M, et al. Hepatic cholesterol metabolism in subjects 
with gallstones: comparative effects of short-term feeding of chenodeoxycholic acid and ursodeoxycholic acid. J Lipid Res 1980; 21: 35-43.

45 Heuman R, Norrby S, Sjödahl R, Tiselius H-G, Tagesson C. Altered gallbladder bile composition in gallstone disease. Relation to gallbladder wall permeability. Scand $J$ Gastroenterol 1980; 15: 581-6.

46 Ahlberg J, Angelin B, Einarsson K. Molecular species of biliary phosphatidylcholines in gallstone patients: the influence of treatment with cholic acid and chenodeoxycholic acid. J Lipid Res 1981; 22: 404-9.

47 Kajiyama M, Yamada K, Horiuchi I, Miyoshi A. The influence of aging upon gallstones changes in serum lipids, lithogenicity of bile and cross-sectional views of stones with age. Hiroshima J Med Sci 1981; 30: 165-74.

48 Angelico M, Attili AF, Cantafora A, et al. Stone composition and gallbladder bile analysis and bacteriology in patients with radiolucent gallstones. Comparison with control subjects. Ital J Gastroenterol 1982; 14: 139-44.

49 Nilsell K, Angelin B, Liljeqvist L, Einarsson K. Biliary lipid output and bile acid kinetics in cholesterol gallstone disease. Evidence for an increased hepatic secretion of cholesterol in Swedish patients. Gastroenterology 1985; 89: 287-93.

50 Rutgeert P, Ghoos Y, Vantrappen G, Fevery J. Biliary lipid composition in patients with non-operated Crohn's disease. Dig Dis Sci 1986; 31: 27-32.

51 Salvioli G. Paper delivered to 9th International Symposium on Bile Acids. Cortina d'Ampezzo, March 20th-22nd, 1986.

52 Hofmann AF, Grundy SM, Lachin JM, et al. Pre-treatment biliary lipid composition in white patients with gallstones in the National Cooperative Gallstone Study. Gastroenterology 1982; 83: 738-52.

53 Alvaro D, Angelico F, Attili AF, et al. Plasma lipid lipoproteins and biliary lipid composition in female gallstone patients. Biomed Biochim Acta 1986; 45: 761-8.

54 Jazrawi RP, Northfield TC. Effects of a pharmacological dose of cholecystokinin on bile acid kinetics and biliary cholesterol saturation in man. Gut 1986; 27: 355-62.

55 van der Linden W, Bergman F. An analysis of data on human hepatic bile. Relationship between main bile components, serum cholesterol and serum triglycerides. Scand J Clin Lab Invest 1977; 37: 741-7.

56 Pomare EW, Heaton KW. Alteration of bile salt metabolism by dietary fibre (bran). $\mathrm{Br}$ Med J 1973; 4: 262-4.

57 Pomare EW, Heaton KW, Low-Beer TS, Espiner HJ. The effect of wheat bran upon bile salt metabolism and upon the lipid composition of bile in gallstone patients. Am J Dig Dis 1976; 21 : 521-6.

58 Tarpila S, Miettinen TA, Metsäranta L. Effects of bran on serum cholesterol, faecal mass, fat, bile acids and neutral sterols and biliary lipids in patients with diverticular disease of the colon. Gut 1978; 19: 137-45.

59 Wicks ACB, Yeates J, Heaton KW. Bran and bile: time-course of changes in normal young men given a standard dose. Scand J Gastroenterol 1978; 13: 289-92.

60 Marcus SN, Heaton KW. Effects of a new, concentrated wheat fibre preparation on intestinal transit, deoxycholic acid metabolism and the composition of bile. Gut 1986; 27: 893-900.

61 Huijbregts AWM, van Berge-Henegouwen GP, Hectors MPC, van Schaik A, van der Werf SDJ. Effects of a standardised wheat bran preparation on biliary lipid composition and bile acid metabolism in young healthy males. Eur J Clin Invest 1980; 10: 451-8.

62 Wechsler JG, Swobodnik W, Wenzel H, et al. Ballaststoffe vom Typ Weizenkleie senken Lithogenität der Galle. Dtsch Med Wochenschr 1984; 109: 1284-8.

63 Heaton KW. Effect of dietary fiber on biliary lipids. In: Barbara L, Porro GB, Cheli R, Lipkin M, eds. Nutrition in gastrointestinal disease. New York: Raven Press, 1987: 213-22.

64 Low-Beer TS, Nutter S. Colonic bacterial activity, biliary cholesterol saturation and pathogenesis of gallstones. Lancet 1978; ii: 1063-5.

65 Carulli N, Ponz de Leon M, Loria P, Iori R, Rosi A, Romani M. Effect of the selective expansion of the cholic acid pool on bile lipid composition: possible mechanism of bile acid induced biliary cholesterol desaturation. Gastroenterology 1981; 81: 539-46.

66 Ponz de Leon M, Carulli N, Iori R, Loria P, Romani M. Regulation of cholesterol absorption by bile acids: role of deoxycholic acid and cholic acid pool expansion on dietary cholesterol absorption. Ital J Gastroenterol 1983; 15: 86-93.

67 Thornton JR, Heaton KW. Do colonic bacteria contribute to cholesterol gall stone formation? Effects of lactulose on bile. Br Med J 1981; 282: 1018-20. 
68 Salvioli G, Salati R, Bondi K, Fratalocchi A, Sala BM, Gibertini A. Bile acid transformation by the intestinal flora and cholesterol saturation in bile. Effects of Streptococcus faecium administration. Digestion 1982; 23: 80-8.

69 Angelin B, Einarsson K, Leijd B. Bile acid metabolism in hypothyroid subjects: response to substitution therapy. Eur J Clin Invest 1983; 13: 99-106.

70 Ahlberg J, Angelin B, Einarsson K, Hellström K, Leijd B. Influence of deoxycholic acid on biliary lipids in man. Clin Sci Mol Med 1977; 53: 249-56.

71 LaRusso NF, Szczepanik PA, Hofmann AF. Effect of deoxycholic acid ingestion on bile acid metabolism and biliary lipid secretion in normal subjects. Gastroenterology 1977; 72: $132-40$.

72 Carulli N, Ponz de Leon M, Zironi F, Iori R, Loria P. Bile acid feeding and hepatic sterol metabolism: effect of deoxycholic acid. Gastroenterology 1980; 79: 637-41.

73 Shiner M. Effects of bile acids on the small intestinal mucosa in man and rats: a light and electron microscopic study. In: Schiff L, Carey B, Dietschy J, eds. Bile salt metabolism. Illinois: Springfield, 1969: 41-5.

74 Gracey M, Papadimitriou J, Burke V, Thomas J, Bower G. Effects on small intestinal function and structure induced by feeding a deconjugated bile salt. Gut 1973; 14: 519-28.

75 Fry RJM, Staffeldt E. Effect of a diet containing sodium deoxycholate on the intestinal mucosa of the mouse. Nature $1964 ; 203$ : $1396-8$.

76 Carulli N, Loria P, Bertolotti M, et al. Effects of acute changes of bile acid pool composition on biliary lipid secretion. J Clin Invest 1985; 74: 614-24.

77 Vlahcevic ZR, Prugh MF, Gregory DH, Swell L. Disturbances of bile acid metabolism in parenchymal liver cell disease. Clin Gastroenterol 1977; 6: 25-43.

78 Angelin B, Einarsson K, Ewerth S, Leijd B. Biliary lipid composition in patients with portal cirrhosis of the liver. Scand J Gastroenterol 1980; 15: 849-52.

79 DiDonato P, Carubbi F, Ponz de Leon M, Carulli N. Effect of small doses of deoxycholic acid on bile cholesterol saturation in patients with liver cirrhosis. Gut 1986; 27: 23-6.

80 Small DM. The formation of gallstones. Adv Intern Med 1970; 16: 243-64.

81 Coleman R Holdsworth G, Vyvoda OS. Hepatocyte surface enzymes and their appearance in bile. In: Popper H, Bianchi L, Reutter W, eds. Membrane alterations as a basis of liver injury. Lancaster: MTP Press, 1977: 143-56.

82 Leiss O, von Bergmann K, Streicher U, Stratkoetter H. Effect of three different dihydroxy bile acids on intestinal cholesterol absorption in normal volunteers. Gastroenterology 1984; 87: 144-9.

83 von Bergmann K. Paper delivered to 9th International Symposium on Bile Acids. Cortina d'Ampezzo. March 20th-22nd, 1986.

84 Pomare EW, Low-Beer TS. Selective suppression of chenodeoxycholate synthesis by cholate metabolites in man. Clin Sci Mol Med 1975; 48: 315-21.

85 Hofmann AF, Lachin JM. Biliary bile acid composition and cholesterol saturation. Gastroenterology 1983; 84: 1075-7.

86 Hillman LC, Peters SG, Fisher CA, Pomare EW. Effects of the fibre components pectin, cellulose, and lignin on bile salt metabolism and biliary lipid composition in man. Gut 1986 27: 29-36.

87 Northfield TC, LaRusso NF, Hofmann AF, Thistle JL. Biliary lipid output during three meals and an overnight fast. II Effect of chenodeoxycholic acid treatment in gallstone subjects. Gut 1975 ; 16: $12-7$.

88 Hofmann AF, Paumgartner G. Chenodeoxycholic acid therapy of gallstones: update. Stuttgart, New York: Schattauer Verlag, 1975.

89 Thistle JL, Hofmann AF, Yu PYS, Ott B. Effect of varying doses of chenodeoxycholic acid on bile lipid and bile acid composition in gallstone patients: a dose response study. $A m \mathrm{~J}$ Dig Dis 1977; 22: 1-6.

90 Admirand WH, Small DM. The physicochemical basis of cholesterol gallstone formation in man. J Clin Invest 1968; 47: 1043-52.

91 Carey MC, Small DM. The physical chemistry of cholesterol solubility in bile: relationship to gallstone formation and dissolution in man. J Clin Invest 1978; 61: 998-1026.

92 Holan KR, Holzbach RT, Hermann RE, Copperman AM, Claffey WJ. Nucleation time: a key factor in the pathogenesis of cholesterol gallstone disease. Gastroenterology 1979; 77: 611-7.

93 Burnstein MJ, Ilson RG, Petrunka CN, Taylor RD, Strasberg SM. Evidence for a potent nucleating factor in gallbladder bile of patients with cholesterol gallstones. Gastroenterology 1983; 85: 801-7.

94 Gollish SH, Burnstein MJ, Ilson RG, Petrunka CN, Taylor.RD, Strasberg SM. Nucleation 
of cholesterol monohydrate crystals from hepatic and gallbladder bile of patients with cholesterol gallstones. Gut 1983; 24: 836-44.

95 Whiting MJ, Watts J McK. Supersaturated bile from obese patients without gallstones supports cholesterol growth but not nucleation. Gastroenterology 1984; 86: 243-8.

96 Lee SP, LaMont JT, Carey MC. Role of gallbladder mucus hypersecretion in the evolution of cholesterol gallstones: studies in the prairie dog. J Clin Invest 1981; 67: 1712-23.

97 Ahlberg J, Curstedt T, Einarsson K, Sjövall J. Molecular species of biliary phosphatidyl choline in gallstone patients: the influence of treatment with cholic and chenodeoxycholic acids. J Lipid Res 1981; 22: 404-9.

98 Cantafora A, Angelico M, DiBiase A, et al. Structure of biliary phosphatidyl choline in cholesterol gallstone patients. Lipids 1981; 16: 589-92.

99 De Benedetto D, Turner B, Handin RI. Indomethacin inhibits gallbladder mucin secretion and prostaglandin release. [Abstract]. Gastroenterology 1981; 80: 1113.

100 van Berge Henegouwen GP, van der Werf SDJ, Ruben AT. Fatty acid composition of phospholipids in bile in man: promoting effect of deoxycholate on arachidonate. Clin Chim Acta 1987; 165: 27-37.

101 Gallinger S, Taylor RD, Harvey PRC, Petrunka CN, Strasberg SM. Effect of mucous glycoprotein on nucleation time of human bile. Gastroenterology 1985; 89: 648-58.

102 Heaton KW, Wicks ACB, Yeates J. Bile composition in relation to race and diet: Studies in Rhodesian Africans and British subjects. In: Paumgartner G, Stiehl A, eds. Bile acid metabolism in health and disease, Lancaster, England: MTP Press, 1977: 197-202.

103 Pomare EW. Fibre and bile acid metabolism. In: Wallace G, Bell L, eds. Fibre in human and animal nutrition. Wellington: Royal Society of New Zealand, 1983; 179-82.

104 van der Werf SDJ, Nagengast FM, van Berge Henegouwen GP, Huijbregts AWM, van Tongeren JHM. Colonic absorption of secondary bile acids in patients with adenomatous polyps and in matched controls. Lancet 1982 ; i: 759-62.

105 Valdivieso V, Palma R, Wünkhaus R, Antezana C, Severin C, Contreras A. Effect of aging on biliary lipid composition and bile acid metabolism in normal Chilean women. Gastroenterology 1978; 74: 871-4.

106 Einarsson K, Nilsell K, Leijd B, Angelin B. Influence of age on secretion of cholesterol and synthesis of bile acids by the liver. N Engl J Med 1985; 313: 277-82.

107 van der Werf SDJ, Nagengast FM, van Berge Henegouwen GP, Huijbregts AW, van Tongeren JHM. Intracolonic environment and the presence of colonic adenomas in man. Gut 1983; 24: 876-80.

108 Low-Beer TS, Pomare EW. Regulation of bile salt pool size in man. Br Med J 1973; 1: 338-40.

109 Northfield TC, Hofmann AF. Biliary lipid secretion in gallstone patients. Lancet 1973; i: 747.

110 Northfield TC, Hofmann AF. Biliary lipid output during three meals and an overnight fast. I. Relationship to bile acid pool size and cholesterol saturation of bile in gallstone and control subjects. Gut 1975; 16: 1-11.

111 Pomare EW, Heaton KW. The effect of cholecystectomy on bile salt metabolism. Gut $1973 ; 14: 753-62$.

112 Almond HR, Vlahcevic ZR, Bell CC, Gregory DH, Swell L. Bile acid pools, kinetics and biliary lipid composition before and after cholecystectomy. N Engl J Med 1973; 289: 1213-6.

113 Roda E, Aldini R, Mazzella G, et al. Enterohepatic circulation of bile acids after cholecystectomy. Gut 1978; 19: 640-9. 